\title{
Diversification of the level of agricultural development in the member states of the European Union
}

\author{
Anna Nowak ${ }^{1, *}$, Paweł Janulewicz ${ }^{2}$, Artur Krukowski ${ }^{1}$ and Barbara Bujanowicz-Haraś ${ }^{2}$ \\ ${ }^{1}$ Department of Economics and Agribusiness, Faculty of Agrobioengineering, University of Life Sciences in Lublin, ul, Akademicka 13, \\ 20-950 Lublin, Poland \\ 2 Department of Management and Marketing, Faculty of Agrobioengineering, University of Life Sciences in Lublin, ul, Akademicka 13, \\ 20-950 Lublin, Poland
}

\begin{abstract}
The paper aimed to evaluate the level of development of agriculture in 25 member states of the European Union (EU) in 2010-2013. The analysis was carried out using the development model proposed by Hellwig, which enabled the calculation of a single synthetic aggregate measure based on the characteristics of agriculture in respective countries. This made it possible to compare the analysed member states, thus providing the basis for allocating them to uniform groups characterised by a similar level of agricultural development. The results indicate that the Netherlands and Denmark are the countries with the highest level of agricultural development. The studies also show that the worst level of development in the ranking is presented primarily by the member states that acceded to the EU in 2004 and later, with agriculture in Slovakia and the Czech Republic being an exception. The diversification of the values of synthetic measure in respective member states points to a considerable diversification of agricultural development within the EU, which is determined both by the production potential and the effectiveness of its utilisation.
\end{abstract}

Keywords: agriculture / European Union / competitiveness / economic development

Résumé - Diversité du niveau de développement de l'agriculture des pays de l'Union européenne. L'objectif de l'article est d'évaluer le niveau de développement de l'agriculture dans les 25 pays membres de l'Union européenne (UE), dans les années 2010-2013. L'analyse a été effectuée en utilisant le modèle de développement d'Hellwig, qui a permis de calculer une mesure synthétique d'agrégat, basée sur les traits caractéristiques de l'agriculture dans chaque pays. Cela a permis de comparer les pays étudiés et de les diviser en groupes homogènes, caractérisés par un niveau semblable de développement de l'agriculture. Les résultats obtenus indiquent que les Pays-Bas et le Danemark sont les pays les plus avancés dans le domaine de l'agriculture. Les recherches montrent aussi que les pays qui sont devenus membres de l'UE en 2004 et dans les années suivantes présentent le plus mauvais niveau de développement de ce classement, à l'exception de la Slovaquie et de la République tchèque. La diversité de valeur de la mesure synthétique dans les pays membres indique une grande diversité du niveau de développement de l'agriculture dans l'UE, qui est déterminé non seulement par le potentiel de production, mais aussi par l'effectivité de son utilisation.

Mots clés : agriculture / Union européenne / productivité / développement économique

\section{Introduction}

Agriculture in the European Union (EU) is characterised by large internal diversification, which is a result of both natural conditions, the potential, the level of social and economic development of respective countries and different lengths of time over which they have been members of the community.

\footnotetext{
* Corresponding author : anna.nowak@up.lublin.pl
}

The differences refer not only to production and economic results but also to the agrarian structure, level of employment in this sector and the significance of agriculture for the national economy. In the countries that have been members of the community for the longest time, thanks to consistent implementation of the Common Agricultural Policy, the agriculture sector has made considerable progress in the area of technology and mechanisation, the consequence of which has been a large increase in production and workforce productivity in agriculture (Chmielewska, 2008). In member 
states that have been a part of the Union since 2004 or acceded at a later date, the situation of agriculture and the rural areas is completely different than in other EU countries (Kijek et al., 2015; Bašek and Kraus, 2011; Terluin, 2003). In her studies, Chmielewska (2008) argues that following each extension of the Union the regional diversification of the fundamental production and social indicators in the agriculture sector and in rural areas deepened. However, the largest changes occurred after 2004 when 12 new member states joined the community.

The diversification of the conditions of agricultural production in respective countries as well as the specific nature of the agricultural sector makes evaluation of the agricultural development level on a national scale quite a difficult task. In order to analyse complex phenomena, such as the level of development or the potential of agriculture, it is necessary to consider many factors (Krasowicz and Kukuła, 2006; Bryden, 2002). Scientific literature makes attempts at evaluating this phenomenon based on different indicators. Table 1 presents selected characteristics of agriculture that were used for evaluating the level of development of this sector.

In order to explain the term "level of agricultural development", it must be integrated in a broader term, that is, "economic development". Economic development is not equivalent to economic growth. Economic growth is the measure of quantitative changes in an economy and denotes an increase in the global production of goods and services by a specific community in a specific time. On the other hand, economic development, in addition to quantitative changes in an economy expressed by means of economic growth indicators, is also inclusive of qualitative changes in the social and economic structure of a country (Soubbotina, 2004).

However, in every country the consequence of fast economic growth is excessive consumption and load on natural resources. An attempt to oppose the materialist concept of welfare following from continuous economic growth is the concept of constant and sustainable development. Its aim is to transform the economy completely into a sustainable economy characterised by sustainable economic, environmental and social development (The World Commission on Environment and Development Report, 1987).

The differentiation of economic development between different member states, which has been seen to deepen since the beginning of the 19th century, is caused by the development of capitalism and, in particular, economic globalisation. The EU is also subject to internal differentiation processes. This is due to an increase in the number of member states in a short time and the inclusion of post-communist states in this group. It pays attention to the high heterogeneity and diverse directions of system changes in this area. They are a result of political, cultural, historical, economic, social and demographic differentiation (Jasiecki, 2014; Stec et al., 2014).

The relationship between agriculture and economic growth is an extensively debated topic. Often, a low productivity level and a slow growth of the agricultural sector are perceived as the main causes for low incomes and slow economic growth in developing countries (Alston and Pardey, 2014). A declining share for agriculture in national employment and gross domestic product (GDP) is an inevitable consequence of economic progress (Cervantes-Godoy and Brooks, 2008; Byerlee et al., 2009). This is largely due to higher income elasticities of demand for non-agricultural goods and services.
Both endogenous (internal) and exogenous (external) conditions are of key significance to the economic situation of agriculture (Bezat-Jarzębowska and Rembisz, 2015). Exogenous conditions cover a large number of factors having a more or less direct impact on transformations in agriculture. These include market, institutional, environmental, macroeconomic and global factors. On the other hand, endogenous conditions derive mainly from its production potential. Among the conditions for agricultural development, general development trends determining the position of this sector in the economy must be also identified. In addition, these trends include environmental hazards pertaining to the present development of civilisation - also with reference to the agricultural sector. The response to the negative effects of agricultural development according to the industrial paradigm, that is, productivism, is the concept of sustainable agriculture (Marsden and Sonnino, 2008). The model is based on the multi-functionality of farms, realised by diversifying their economic activity, but also on intensive farms that are highly competitive in the global market (Rizov, 2006; Renting et al., 2009).

Agricultural development is understood as quantitative and qualitative changes occurring in the agricultural sector in an analysed period (Siudek, 2008), whereas the level of development is a certain condition achieved as a result of such changes. Determining the level of development is a complex and difficult issue due to the selection of adequate indicators and limited possibility of obtaining data for all the analysed units in different time slices (Jezierska-Thöle et al., 2014). This work aims to evaluate the level of agricultural development in 25 countries of the EU between 2010 and 2013 according to selected indicators. The studies did not take into account Malta, Cyprus and Croatia - the first two were excluded due to the small significance of agriculture in those countries, and Croatia, due to the fact that it joined the community in 2012 - thus access to data characterising agriculture is limited in this case. The study adopted an approach consistent with the classical paradigm in which the microeconomic efficiency criterion is predominant. However, the authors are aware of the diversity of factors shaping its level of development and of the significance of external effects generated by this sector. Such an approach to the studies is due to the large differentiation of the production potential of agriculture and its effective use in the member states of the EU. It means that in some countries the strategy of agricultural development should still be largely based on quantitative changes, while in others, more on qualitative changes taking into account ecological and social factors.

\section{Materials and methods}

For the purposes of identifying the level of agricultural development in 25 countries forming part of the EU, one of the most popular taxonomic methods was used - the development model proposed by Hellwig. It is a model variable aggregation formula based on a constructed model, so-called development model created on the basis of the optimum variable values (most optimum ones in the whole group). Thus, it is a clustering technique. This method synthesizes factors of a different nature (originating from different sources) and allocates them to a single, synthetic aggregate measure (Mika, 1995). Applied 
Table 1. Review of selected studies concerning the level of agricultural development.

Tableau 1. Présentation de différentes recherches sur le niveau de développement de l'agriculture.

\begin{tabular}{|c|c|c|}
\hline Authors & $\begin{array}{l}\text { Subject of research and years } \\
\text { covered by the study }\end{array}$ & Variables used in the assessment of agriculture development \\
\hline $\begin{array}{l}\text { Janiszewska and } \\
\text { Ossowska (2014) }\end{array}$ & $\begin{array}{l}\text { Agriculture of EU countries, } \\
2010\end{array}$ & $\begin{array}{l}\text { Average area of total utilised agricultural area (UAA) on farm (ha), total livestock } \\
\text { output per large unit (euro/LU), total UAA per } 1 \text { AWU (ha/AWU), land } \\
\text { productivity - total output/total UAA (euro/ha), crop yields (dt/ha) }\end{array}$ \\
\hline Binderman (2012) & $\begin{array}{l}\text { Polish voivodships, the years } \\
1998-2010\end{array}$ & $\begin{array}{l}\text { Share of agricultural land in total farm area, the indexation rate of agricultural } \\
\text { production area (points), yields of sugar beets (tonnes per ha), livestock per } 100 \text { ha } \\
\text { of agricultural land, procurement of potatoes (kg per } 1 \text { ha agricultural land), } \\
\text { procurement of rape and turnip rape (kg per } 1 \text { ha cultivation area), procurement of } \\
\text { fruit from trees (kg per } 1 \text { ha cultivation area), procurement value of agricultural } \\
\text { products (PLN per } 1 \text { ha agricultural land), the number of tractors (per } 100 \text { ha } \\
\text { agricultural land), investment in agriculture (PLN per } 1 \text { ha agricultural land) }\end{array}$ \\
\hline Siudek (2008) & $\begin{array}{l}\text { Polish voivodships, the years } \\
\text { 1997-2006 }\end{array}$ & $\begin{array}{l}\text { Farm net value added/AWU (euro/AWU), area of total UAA in farm (ha), } \\
\text { employment and the value of agricultural production per } 1 \text { ha }\end{array}$ \\
\hline
\end{tabular}

Source: own elaboration.

during the analyses, this method made it possible to synthetically compare the selected 25 member states, thus providing the basis for allocating them to uniform groups characterised by a similar level of agricultural development.

Research was carried out based on data from Eurostat. At the first stage of the research procedure, the indicators were initially selected based on studies of reference literature. Fifteen diagnostic variables were selected; then they were verified in terms of formal criteria, i.e. whether they are measurable, complete and comparable. At the following stage, taking statistical criteria into account, quasi-constants, that is constants for which the coefficient of variation did not exceed $10 \%$, were eliminated. Hence, the following indicators were removed from the set: economic size of the farm (in EUR), stocking density (LU/100 ha utilised agricultural area [UAA]), value of agricultural production per 1 farm (in EUR), intermediate consumption per 1 ha of arable land and average income of a farm (in EUR). Finally, 10 diagnostic variables were used in the research, which made it possible to determine the level of agricultural development in the analysed countries by means of a synthetic measure:

- $X_{1}$ : average area of total UAA in farm (ha);

- $X_{2}$ : total UAA per 1 AWU (ha/AWU);

$-X_{3}$ : total livestock output per large unit (euro/LU);

$-X_{4}$ : gross investment per 1 farm (euro);

$-X_{5}$ : wheat yield (dt/ha);

$-X_{6}:$ milk yield (litre);

- $X_{7}$ : land productivity - total output/total UAA (euro/ha);

- $X_{8}$ : labour productivity - farm net value added/AWU (euro/ AWU);

- $X_{9}$ : the potential capital productivity - total output/total fixed assets (euro/1 euro);

- $X_{10}$ : current capital productivity - total output/total inputs (euro/1 euro).

The procedure of Hellwig methods is summarized in four steps.

\subsection{Step 1: normalization of alternative values}

In order to normalize the features, the standardization procedure was used based on the following formula (Adamowicz and Janulewicz, 2012):

$$
z_{i j}=\frac{x_{i j}-\bar{x}_{i j}}{s_{j}}
$$

where: $i$ - object number; $j$ - features number.

\subsection{Step 2: calculating the taxonomic distance between the analysed object and the benchmark by means of the taxicab metric according to the formula}

$$
d_{i}=\sum_{j=1}^{m}\left|z_{i j}-z_{0 j}\right|
$$

\subsection{Step 3: calculating Hellwig's synthetic development measure $\left(z_{i}\right)$}

$$
z_{i}=1-\frac{d_{i}}{d_{0}}
$$

where:

$d_{0}=\bar{d}+3_{S_{d}}, \quad \bar{d}=\frac{1}{n} \sum_{i=1}^{n} d_{i}, \quad s_{d}=\sqrt{\frac{1}{n} \sum_{i=1}^{n}\left(d_{i}-\bar{d}\right)^{2}}$,

where: $0 \leq z_{i} \leq 1$.

The values of the indicator assume values in the range $<0 ; 1>$, whereas they are closer to the benchmark so they are characterised by a high level of development of the analysed object. 
Table 2. Statistical characteristics of diagnostic variables in the selected 25 member states of the European Union. Tableau 2. Caractéristiques statistiques des variables diagnostiques des 25 pays choisis dans l'Union européenne.

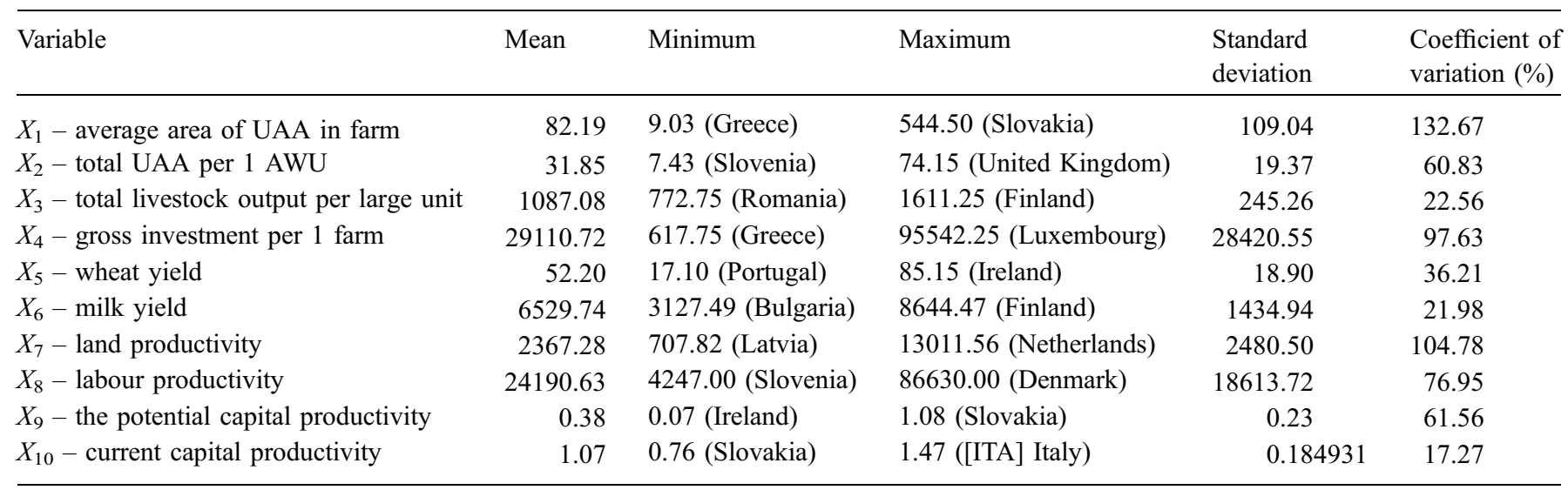

Source: own elaboration based on data from Eurostat.

\subsection{Step 4: ranking the preference order}

On the basis of synthetic measure $z_{i}$, mean and standard deviation administrative units were divided into four typological classes representing different level of the research issue:

- class I: $z_{i} \geq \bar{z}+s_{z}$

- class II: $\bar{z} \leq z_{i}<\bar{z}+s_{z}$;

- class III: $\bar{z}-s_{z} \leq z_{i}<\bar{z}$;

- class IV: $z_{i}<\bar{z}-s_{z}$.

where: $\bar{z}-$ mean; $s_{z}-$ standard deviation.

\section{Results of the research}

All the above-presented variables were considered boosters (the-larger-the-better characteristics) with high values being desirable from the point of view of the studied phenomenon. Statistical characteristics presented in Table 2 were determined for the features covered by the study. The table presents disproportions between the analysed member states of the EU illustrated, among other things, by means of minimum values, maximum values and the coefficient of variation.

The values of the coefficient of variation of the characteristics in use ranged from about $17.27 \%$ to about $132 \%$. The highest diversification was recorded in terms of the average area of arable land per farm $(V=132.67 \%)$ and land productivity $(V=104.78 \%)$. The lowest variability occurred for a variable describing the current productivity of capital $(V=17.27 \%)$, the milk yield of cows $(V=21.97 \%)$ and the value of animal production per $1 \mathrm{LU}(V=22.56 \%)$.

Based on the analyses the EU member states covered by the study were classified into four groups according to the synthetic measure of the degree of agricultural development. The most developed group I comprised two countries, i.e. the Netherlands and Denmark, with the synthetic measure assuming the values of 0.601 and 0.586 , respectively. Studies by Domańska et al. (2014) indicate that Denmark is also a country which, similar to Ireland, in 2007-2011, among the socalled "old 15 member states", recorded an increase in total productivity in agriculture. Group II included 10 countries with a more than average level of agricultural development: Slovakia (0.472), Belgium (0.467), Germany (0.462),
United Kingdom (0.460), France (0.449), Sweden (0.438), Luxembourg (0.424), the Czech Republic (0.398), Estonia (0.377), and Finland (from 0.375). Group III, presenting the EU's average level of agricultural development, consisted of eight countries, i.e. Italy (0.338), Austria (0.337), Hungary (0.329), Ireland (0.292), Lithuania (0.283), Spain (0.278), Latvia (0.261), and Greece (0.249). Countries with the lowest level of agricultural development, classified in group IV, are four new member states of the community - Poland (0.228), Romania (0.227), Bulgaria (0.203), and Slovenia (0.186) and one country that has been a member of the EU for a considerably longer time - Portugal (0.177) (Tab. 3).

Table 4 shows the average values of indicators selected for analysis in four groups formed with regard to the level of agricultural development in the analysed EU member states. According to the presented data, the average area of a farm and the area of arable land per full-time farm employee had no decisive effect on the classification of the specific country into the group with the highest level of development, since the largest (151.53 ha) average area of arable land on farms was characteristic of countries classified into group II, whereas in group I this value was greater than $65 \mathrm{ha}$, while the average for all the 25 member states covered by the study was 82.19 ha. The area of arable land per full-time farm employee is similar - in group II, it is 47 ha, while in group I, it is 34 ha, while the average is close to $32 \mathrm{ha}$.

A clearer situation occurs with reference to economic indicators describing the effectiveness of agricultural activity since the value of the indicators decreases in groups presenting lower levels of agricultural development. For instance, large discrepancies between countries assigned to respective groups occur with regard to animal production, since in countries classified in group I the value is higher than EUR 1537/SD, while in group IV it remains at the level of EUR 845.60. This is largely due to the diversification of effects of the agricultural activity. For instance, in group I, the milk yield of cows is 8278.45 litres, whereas in group IV it is lower by nearly one half, at 4770.80 litres. In the case of wheat crop yield, this is $76.4 \mathrm{dt}$ for countries from group I and $38.3 \mathrm{dt}$ for countries from group IV, whereas the average for the analysed farms is $52.2 \mathrm{dt}$. Also, the level of farm investments in the countries covered by the study is 
Table 3. Classification of European Union countries with regard to values of the partially synthetic measure describing the level of agricultural development.

Tableau 3. Classement des pays de l'Union européenne, en prenant en compte la valeur de mesure partielle synthétique, décrivant le niveau de développement de l'agriculture.

\begin{tabular}{lcll}
\hline Group number & $\begin{array}{l}\text { The number of } \\
\text { countries in the group }\end{array}$ & $\begin{array}{l}\text { The level of } \\
\text { measurement }\end{array}$ & The member states of the European Union \\
\hline I & 2 & $\begin{array}{l}\text { Over } 0.475 \\
\text { From } 0.356 \text { to } 0.475\end{array}$ & $\begin{array}{l}\text { Netherlands, Denmark } \\
\text { Slovakia, Belgium, Germany, United Kingdom, France, Sweden, } \\
\text { II }\end{array}$ \\
& 10 & Fuxembourg, Czech Republic, Estonia, Finland \\
III & 5 & Below 0.237 to 0.356 & $\begin{array}{l}\text { Italy, Austria, Hungary, Ireland, Lithuania, Spain, Latvia, Greece } \\
\text { Poland, Portugal, Romania, Bulgaria, Slovenia }\end{array}$ \\
IV & 5 &
\end{tabular}

Source: own elaboration based on data from Eurostat.

Table 4. Average values of the variables describing the level of agricultural development in 25 European Union member states.

Tableau 4. Valeurs moyennes des variables déterminant le niveau de développement de l'agriculture dans les 25 pays de l'Union européenne.

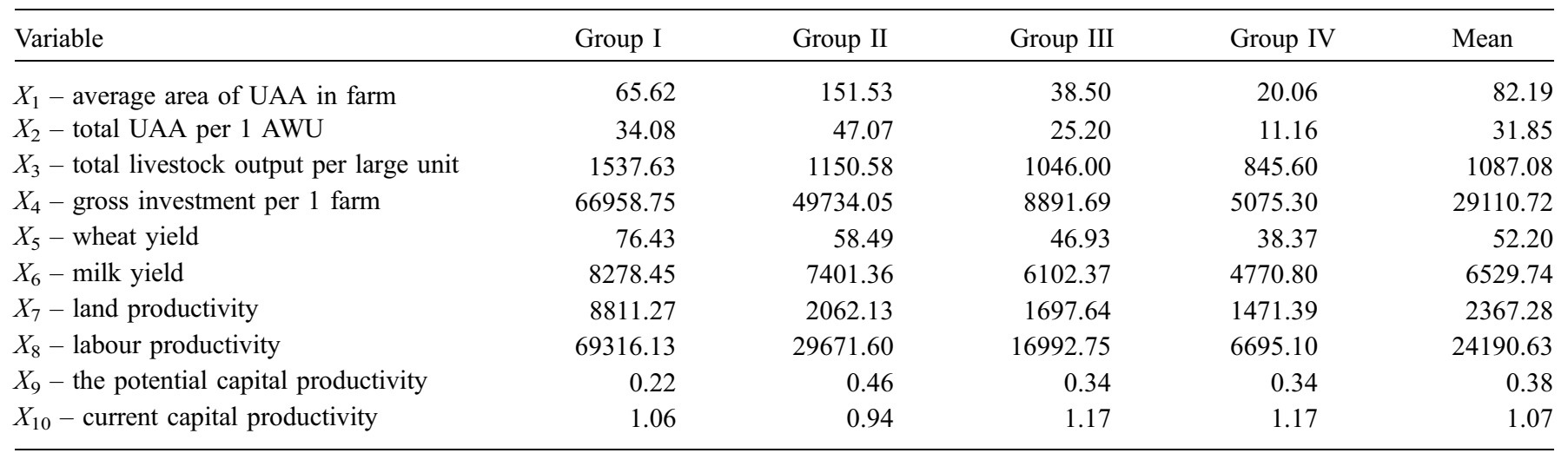

Source: own elaboration based on data from Eurostat.

diversified. The largest investment expenditure on farms were recorded in countries from group I, in which they amounted to EUR 66,958.70 per farm, whereas the lowest level (EUR $5,075.30$ ) was noted for countries forming group IV, with the average for the analysed countries being EUR 29,110.70.

The situation is similarly diversified in the case of productivity levels of production factors used in agriculture. Productivity is commonly recognised as the main indicator of the level of economic development (Soubbotina, 2004). The average land productivity in the EU in the analysed years was EUR 2,367.30 per 1 ha UAA. The highest land productivity in agriculture is noted in countries from group I, that is, the Netherlands and Denmark. In 2010-2013 it was EUR 8811.20/ ha on average, whereas in agricultures of countries from group IV it was much lower - only EUR 1471.4/ha.

The most diversified are workforce productivity indicators which tend to decrease along with the decreasing level of agriculture in the classified groups. In the case of agriculture in countries from group I the indicators amount to EUR 69,316 per full-time farm employee, whereas in countries from group IV the value is more than 10 times lower (EUR 6,695). In the group of all the examined 25 countries the ratio is EUR 24,190/ AWU. Strong differentiation of workforce productivity in the agriculture of the EU member states was also noted by Klíma and Palát (2005). Labour productivity increase in the agricultural sector is considered as one of the determinants of overall economic growth (Dorward, 2013).

The average potential productivity of capital expressed as the relation of production value to the value of fixed assets ranged from EUR 0.22 in the group of countries presenting the highest level of agricultural development to EUR 0.46 in the second group, showing no upward trend along with the level of agricultural development. The least diversified characteristic within the groups was the current productivity of capital determining the effectiveness of utilisation of total costs incurred on farms. The average level of this indicator for all the groups was 1.07 in the analysed period, while the lowest value of production generated by EUR 1 of total costs was achieved by farms in countries from the second group.

\section{Conclusions}

The study evaluated the level of agricultural development in 25 member states of the EU. To this end, a synthetic measure was used based on the development model proposed by Hellwig which made it possible to identify countries characterised by a similar level of the analysed phenomenon. The added value of the research and its contribution to agricultural economics literature is demonstrated by the 
adopted synthetic measure designed on a broad range of variables describing the level of agricultural development, including its potential and effectiveness. An additional advantage offered by the studies is their subjective scope covering a group of 25 member states of the community, which according to the authors' knowledge is rare with reference to the evaluation of the level of agriculture.

The results of research point to strong diversification of the level of agricultural development among the member states of the EU. The value of the synthetic measure of the country with the highest level of development of this sector (the Netherlands) was more than three times higher than in the country that was the least competitive in that respect (Slovenia). The diversification is determined by many factors including both the production potential and the effectiveness of its utilisation. The authors are also aware of the diversification of economic and natural conditions in the agriculture of respective countries as well as historical conditions of the development of this sector. The studies indicate that the worst in the ranking of agricultural development level are mainly those countries whose accession to the EU took place in 2004 or afterwards. The analysis of the global agricultural development paths points to the fact that the fundamental factor of development has been the maximisation of the effectiveness of management of the production factors (Kowalski et al., 2011). Thus, it should be considered that the strategy of further development of this sector, in particular in new member states, remains the improvement of production factors in production processes in agriculture. It requires structural transformations in agriculture in countries which to a large extent are shaped by the mechanisms and instruments of the Common Agricultural Policy. In addition, the rate of changes occurring in agriculture will be connected with the level of agricultural development of the respective countries. This results from the fundamental economic correctness pointing to the relationship between the level of development of the country and the development of the country's agriculture.

The authors are aware that the study method used is only one of the possible options. Since only selected, mainly quantitative aspects of the level of development of this sector were analysed, further studies should take into account the additional scope of variables referring to qualitative changes.

\section{References}

Adamowicz M, Janulewicz P. 2012. Wykorzystanie metod wielowymiarowych w określeniu pozycji konkurencyjnej gminy na przykładzie województwa lubelskiego (The use of multidimensional methods in defining the competitive position of the community on the example lubelskie voivodeship). Metod Ilościowe Bad Ekon 13(1): 17-28.

Alston JM, Pardey PG. 2014. Agriculture in the global economy. $J$ Econ Perspect 28(1): 121-146.

Bašek V, Kraus J. 2011. Comparison of selected indicators of farms in the EU member states. Agric Econ 57(2): 71-84.

Bezat-Jarzębowska A, Rembisz W. 2015. Endo-i egzogenne zródła wzrostu gospodarczego $\mathrm{w}$ rolnictwie-zarys problemu (The endogenous and exogenous sources of growth in agriculture - outline of the problem). Rocz Naukowe Ser 17(6): 19-24.
Binderman A. 2012. Rozwój polskiego rolnictwa w kontekście regionalnego zróżnicowania w latach 1998-2010 (Development of Polish agriculture in the context of regional diversification in 1998-2010). Metod Ilościowe Bad Ekon XIII/3(s): 52-64.

Bryden J. 2002. Rural development indicators and diversity in the European Union. In: Paper presented at the conference on "Measuring rural diversity". Washington, DC. Available from http://citeseerx.ist.psu.edu/viewdoc/download?doi=10.1.1.199.4439 \&rep=rep $1 \&$ type $=$ pdf.

Byerlee D, de Janvry A, Sadoulet E. 2009. Agriculture for development: toward a new paradigm. Annu Rev Res Econ 1: 15-35.

Cervantes-Godoy D, Brooks J. 2008. Smallholder adjustment in middle-income countries: issues and policy responses. In: $O E C D$ Food, Agriculture and Fisheries Working Papers, No. 12. Paris: OECD.

Chmielewska B, ed. 2008. Kierunki rozwoju rolnictwa i obszarów wiejskich w Polsce i w wybranych krajach europejskich (Lines of development of agriculture and rural areas in Poland and in selected European countries). Warszawa: IERiGŻ.

Domańska K, Kijek T, Nowak A. 2014. Agricultural total factor productivity change and its determinants in EU countries. Bulg $J$ Agric Sci 6: 873-882.

Dorward A. 2013. Agricultural labour productivity, food prices and sustainable development impacts and indicators. Food Policy 39: 40-50.

Janiszewska D, Ossowska L. 2014. Zróżnicowanie rolnictwa krajów Unii Europejskiej na podstawie wybranych cech (Diversification of agriculture in the member states of the European Union according to selected characteristics). Zesz Naukowe SGGW Warsz Probl Rol Świat 14(1): 44-54.

Jasiecki K. 2014. Polska transformacja w perspektywie różnorodności kapitalizmu (The Polish systemic transformation from the perspective of the diversity of capitalism). Prz Socjol 63(4): 45-66.

Jezierska-Thöle A, Kluba M, Biczkowski M. 2014. Poziom rozwoju rolnictwa Polski i Niemiec Wschodnich (The level of agricultural development of Poland and East Germany). Rocz Naukowe Ser 16(6): 182-188.

Kijek T, Nowak A, Kasztelan A, Krukowski A. 2015. Agricultural total factor productivity changes in the new and the old European Union members. In: Proceedings of the 7th International Scientific Conference Rural Development. 2015. http://dx.doi.org/10.15544/ RD.2015.084.

Klíma J, Palát M. 2005. Assessing the development of labour productivity in the EU countries. Zemed Ekon 51(11): 489-494.

Kowalski A, Figiel SZ, Halamska M. 2011. Społeczne i ekonomiczne uwarunkowania rozwoju sektora rolno-żywnościowego (Social and economic conditions for the development of the agriculture and food sector). Pol J Agron 7: 29-42.

Krasowicz S, Kukuła S. 2006. Regionalne zróżnicowanie polskiego rolnictwa w świetle badań IUNG-PIB (Regional diversification of Polish agriculture in the light of research carried out by IUNG-PIB). Acta Agr Silv Sekc Ekon 46(2): 73-89.

Marsden T, Sonnino R. 2008. Rural development and the regional state: denying multifunctional agriculture in the UK. J Rural Stud 24(4): 422-431.

Mika J. 1995. Analiza statystyczna pozycji Polski na tle krajów Unii Europejskiej (Statistical analysis of the position of Poland in comparison to member states of the European Union). Katowice: Spółka z o.o. "Śląsk".

Renting H, Rossini WAH, Groot JCJ, Van der Ploeg JD, Laurent C, Perraud D, et al. 2009. Exploring multifunctional agriculture. A review of conceptual approaches and prospects for an integrative transitional framework. J Environ Manag 90: 112-123. 
Rizov M. 2006. Rural development perspectives in enlarging Europe: the implications of CAP reforms and agricultural transition in accession countries. Eur Plan Stud 14: 219-238.

Siudek T. 2008. Wpływ poziomu rozwoju rolnictwa na wartoś ć udzielanych kredytów dla gospodarstw rolnych w Polsce (The effect of the level of agricultural development on the value of loans granted to farms in Poland). Zesz Naukowe SGGW Warsz 69(7): 5-15.

Soubbotina TP. 2004. Beyond economic growth. An introduction to sustainable development. Washington, DC: The World Bank.
Stec M, Filip P, Grzebyk M, Pierscieniak A. 2014. Socio-economic development in the EU member states - Concept and classification. Inz Ekon - Eng Econ 25(5): 504-512.

Terluin IJ. 2003. Differences in economic development in rural regions of advanced countries: an overview and critical analysis of theories. J Rural Stud 19(3): 327-344.

The World Commission on Environment and Development Report. 1987. Our common future. An annex to document A/42/427 Development and international co-operation: environment. Oslo.

Cite this article as: Nowak A, Janulewicz P, Krukowski A, Bujanowicz-Haraś B. 2016. Diversification of the level of agricultural development in the member states of the European Union. Cah. Agric. 25: 55004. 